\title{
The birth of minority legislation in the newly independent Finland and Estonia (1918-1920): a comparative analysis
}

\section{Kari Alenius}

University of Oulu, E-mail: kari.alenius@oulu.fi

https://orcid.org/0000-0002-0339-2922

\begin{abstract}
This article analyzes how ethnic minorities were taken into account in the Finnish and Estonian constitutions, and why account was taken precisely in a certain way. At the same time, it approaches what kinds of views were presented by different political parties and interest groups, what kind of debate was being held in Parliament and how the matter was dealt with in the leading media. The outcome of the process in both countries was that exceptionally broad linguistic and cultural rights were given to minorities if the situation was compared with the rest of Europe.
\end{abstract}

There were several factors behind the process. One factor was the relationship between ethnic groups in Finland and Estonia in the historical perspective. Another factor was each country's internal debate on what kind of social order in general was to be built. The third factor was how the politics in Finland and Estonia was influenced by international trends and theories about how ethnic minorities should have been treated.

\section{Rezumat}

Acest articol analizează modalitatea în care au fost tratate minoritățile etnice $\hat{\imath}$ constituțiile finlandeză și estoniană și cauzele acestor abordări. In același timp, răspunde la întrebarea ce fel de opinii au fost prezentate de diferite partide politice și grupuri de interese, ce fel de dezbateri au avut loc în Parlament și cum a fost reflectată tematica în mass-media principale. Rezultatul procesului de dezbateri din ambele țări a fost că au fost acordate minorităților drepturi lingvistice și culturale excepțional de largi, dacă ar fi să le comparăm cu ceea ce se întâmpla în restul Europei.

In spatele acestui proces au existat mai mulți factori. Un factor a fost relația dintre grupurile etnice din Finlanda și Estonia din perspectiva istorică. Un alt factor a fost dezbaterea internă din cadrul fiecărei țări cu privire la ce fel de ordine socială urma să fie constituită, în general. Al treilea factor a fost constituit de maniera în care politica din Finlanda și Estonia a fost influențată de tendințele și teoriile internaționale cu privire la drepturile care ar fi trebuit acordate minorităților etnice.

Keywords: cultural capital, heritage language, language and identity, migration

CC BY-SA License (https://creativecommons.org/licenses/by-sa/2.0)

This paper has been presented at the Ninth Annual International Conference on Baltic and Nordic Studies in Romania: 100 Years since Modern Independence and Unification in Baltic Sea Region and East-Central Europe held in Târgoviște, Romania during November 15-16, 2018. 


\section{Introduction}

The aim of this article is to examine the extent to which the minority policy carried out by Finland and Estonia resembled that of their counterparts in other European countries. In this context, the minorities are ethnic/national minorities. Others, such as religious minorities, are excluded from this examination. Minority policy refers to legislation concerning minorities and its implementation in practice. The time period examined begins from the declarations of independence of both countries and ends about the year 1920, by which time laws affecting the status of minorities were enacted and their implementation had begun. From a legal and practical perspective, from this point onwards minority policies remained virtually unchanged until the mid-1930s.

Basic research exists in regard to minority policies in Finland and Estonia, and the main points are fairly clear. ${ }^{1}$ So far however, little attention has been given to how minority policy in Finland and Estonia in the early years of independence compares with the corresponding solutions of other countries. This is precisely why this article justifiably focuses on this perspective. In addition to reconstructing similarities and differences, it is essential to look for answers as to why Finland and Estonia partly resembled other countries and partly differed from them. This analysis also includes comparisons between Finland and Estonia.

For this article Finnish and Estonian laws and other key official documents which define the status of minorities have been systemically perused. Other primary documents such as those related to the legislative process, correspondence between authorities, the archives of political parties and newspapers and other published material appearing during the period in question, have been reviewed when applicable. Comparisons to other

\footnotetext{
${ }^{1}$ See, for instance, Erik Allardt \& Christian Starck, Vähemmistö, kieli ja yhteiskunta (Helsinki: WSOY 1981); Juha Pentikäinen \& Marja Hiltunen, Suomen kulttuurivähemmistöt (Helsinki: Suomen Unesco-toimikunta 1997); Pasi Saukkonen, Erilaisuuksien Suomi (Helsinki: Gaudeamus 2013); Kari Alenius, Ajan ihanteiden ja historian rasitteiden ristipaineissa. Viron etniset suhteet vuosina 1918-1925 (Rovaniemi: PSHY 2003); Kaido Laurits, Saksa kultuuromavalitsus Eesti Vabariigis 1925-1940 (Tallinn: Rahvusarhiiv 2008); Anni Matsulevitš Anni (Ed.). Vähemusrahouste kultuurielu Eesti Vabariigis 1918-1940 (Tallinn: Olion 1993).
} 
countries have been carried out partially with the help of legislative texts and earlier studies that deal with minority policy from a more general perspective. In addition to historical source criticism and the comparative method, in preparing this article particular attention in research methods has been given to political rhetoric and the study of perception.

Observing rhetoric is important, as communication does not only reflect reality but always attempts to shape it. The intended role of communication in legal texts to shape is almost always self-evident, but in principle the same also applies to other texts and speeches. The same significance of perception in forming opinion has been confirmed through multidisciplinary research. People make judgments on the basis of their perceptions, regardless of how close to "reality" their "right" or "wrong" perceptions are. For example, in legally defining the position of minorities, it is inevitable that the end result will be affected by what kinds of perceptions legislators have on the basis of their past experiences. At the same time it must be noted that perception is not only affected by information, but by beliefs, fears, desires, attitudes and opinions - in short, an individual's entire past experience. ${ }^{2}$

The end of the First World War and the aftermath until the early years of the 1920s was a time in which the status of minorities became a focus of reassessment. This was necessary particularly in newly independent countries, in which all legislation had to be perused and old laws examined to the extent that they were still usable. As a basis there could be a varying range of laws that a former ruler, for example Austria-Hungary or Imperial Russian, had enacted. In most cases, new states drafted minority legislation and other laws from bottom up to meet the needs of the newly independent state and its new ruling groups. It was ordinary that a national minority of a

\footnotetext{
2 Manfred Beller, "Perception, image, imagology", in Manfred Beller \& Joep Leerssen (Eds.), Imagology. The cultural construction and literaty representation of national characters. A critical survey (Amsterdam: Rodopi 2007), pp. 4-7; Olavi K. Fält, "Introduction”, in Kari Alenius, Olavi K. Fält \& Seija Jalagin (Eds.), Looking at the Other: Historical study of images in theory and practice (Oulu: Oulun yliopisto 2002), pp. 8-11; David Ratz, "The Study of Historical Images", in Faravid. Journal for Historical and Archaeological Studies 31/2007, pp. 189-213.
} 
previously broad empire became the leading ethnic group of a newly independent small state. ${ }^{3}$

The status of minorities was also the subject of debate and consideration in old states. The breakthrough of nationalism and parliamentary democracy, the extension of general civil rights and the promises given for these developments for various reasons in many countries during the war at the very least forced an examination of whether legislation concerning minorities was up to date. For example, in Germany the legal status of minorities changed for the better from their perspective immediately after the war, when Germany transitioned from empire to democracy and former nationalist ruling parties lost their leading position. ${ }^{4}$ In this article, the development of Finland and Estonia is compared to Germany in particular, as this kind of comparison helps better identify what the differences and similarities between the great powers and small nations were in this context.

Minorities and their traditional relationship with the majority population in Finland and Estonia

When the population structures of Finland and Estonia and their ethnic relationships after World War I are inspected, it can be seen that the states closely resembled each other. Out of all the countries that became independent as a result of World War I, Finland and Estonia were the most ethnically homogeneous; in each country the share of the main nationality was around 88 percent. In eastern Central Europe this was clearly the highest percentage overall. Only in Albania and Hungary was the share of the main nationality at the same level, but in all other countries it fell below 80 percent. In fact, Czechoslovakia and Yugoslavia did not even have an actual majority,

\footnotetext{
${ }^{3}$ Eric Hobsbawm, Nations and nationalism since 1780. Programme, myth, reality (Cambridge: Cambridge University 1990), pp. 131-145.

${ }^{4}$ Kari Alenius, Compromise solutions through careful consideration. The development of the legal status of national minorities in Germany, 1918-1919 (Rovaniemi: PSHY 2011), pp. 204-214; Thomas Göthel, Demokratie und Volkstum. Die Politik gegenüber den nationalen Minderheiten in der Weimarer Republik (Köln: SH-Verlag 2002), pp. 395-403.
} 
as the share of even the largest ethnic groups of the total population remained below 50 percent. ${ }^{5}$

Therefore, the basic premise of ethnic policies in Finland and Estonia was clear. Both countries had a strong majority population, and the share of all minorities in total was quite small. Based on this, there was no significant power struggle to be expected between the majority and the minorities with regard to policies applied to the whole state. On the other hand, in both Finland and Estonia the minorities mainly lived in small areas that could be defined quite clearly. ${ }^{6}$ This is why the minority ethnic groups were a majority in many municipalities, challenging the main nationality's (ethnically Finnish or Estonian) position of power at the local level. As the minorities inhabited border regions in Finland and Estonia, a possible threat of separatism arose. In regards to their residential area, potentially separatist minorities were the Swedes, Latvians and Russians in Estonia, and the Swedes in Finland.

In both Finland and Estonia, the Swedish-speaking population lived in a narrow zone on the western coast and the islands nearby. In the beginning of the 1920s Estonia had five municipalities with a Swedishspeaking majority, and the Swedes were also a significant minority in three municipalities. The total number of Estonian Swedes was only about 8,000 people, but due to this strong centralisation of their inhabitation they had a locally strong influence. ${ }^{7}$ Finland had about 340,000 Swedish-speaking citizens who were the majority in 30 municipalities. Additionally, 40 other municipalities had a significant minority of Swedish-speaking residents (10$50 \%) .^{8}$

Based on the preliminary border agreement, there were a few less Latvians than Swedes in Estonia, but otherwise their situation was similar.

\footnotetext{
${ }^{5}$ Raymond Pearson, National minorities in Eastern Europe 1848-1945 (London: Macmillan 1983), pp. 147-149.

6 Rein Ruutsoo, "Rahvusvähemused Eesti Vabariigis", in Matsulevitš 1993, pp. 5-9; Saukkonen 2013, pp. 160, 173.

${ }^{7}$ Alenius 2003, pp. 36-37; Ruutsoo 1993, p. 7.

${ }^{8}$ Allardt \& Starck 1981, pp. 101-107; Karmela Liebkind, Roger Broo \& Fjalar Finnäs, "Suomen ruotsinkielinen vähemmistö", in Pentikäinen \& Hiltunen 1997, pp. 62-65.
} 
There was no traditional administrative boundary line between Estonia and Latvia that would have been based on ethnic Estonian and Latvian residential areas. The Governorate of Livonia was roughly divided along ethnic lines in the spring of 1917 , but the final border agreement between independent Estonia and Latvia was the subject of lengthy negotiations. The agreement reached in 1920 was still changed in 1924, when Estonia ceded to Latvia the southern part of the municipality of Laura, where there were Latvians and Russians but hardly any Estonians. ${ }^{9}$ In practice, this consensus virtually eliminated the threat of Latvian separatism in Estonia, although there still remained a few thousand Latvians in Estonia.

Furthermore, as a consequence of the 1920 Treaty of Tartu, there were relatively large areas with a Russian majority in the vicinity of the eastern border of Estonia. Most of Petseri County as well as the area east of the Narva River belonged to this category. The western coast of Lake Peipus also had a few municipalities where the number of Russian residents exceeded the amount of Estonian residents. From the Estonian perspective, Petseri County and the area east of the Narva River were the biggest threats to security, as the local Russian people did not have many connections to Estonia and the Estonian people before 1920. Instead, their connections had traditionally been directed towards the east and the other governorates of the Russian Empire. The local Russian people who suddenly became Estonian citizens in 1920 did not yet feel any particular loyalty towards the unfamiliar Estonian state. $^{101}$

In Estonia, Germans were a substantial minority group due to their previous position of power and their related elite economic and cultural status. Although Germans were only about two percent of the Estonian population, at the time of Estonian independence they owned more than half of the country's cultivated area. They were also represented many times over in other economic and cultural spheres of life in relation to their population.

\footnotetext{
${ }^{9}$ Eesti Riigiarhiiv (hereafter cited as "ERA", Estonian National Archives), F. 4893, p. 1; Kalle Lõuna, Petserimaa. Petserimaa integreerimine Eesti Vabariiki 1920-1940 (Tallinn: Eesti entsüklopeediakirjastus 2003), pp. 33-36.

${ }^{10}$ Jüri Ant, Eesti 1920. Iseseisvuse esimene rahuaasta (Tallinn: Olion 1990), pp. 63-66; Lõuna 2003, pp. $26,43,47$.
} 
Since the Germans lived scattered all over Estonia, and Germany was not a bordering country to Estonia, the Estonians did not have to fear territorial separatism from the Germans. On the other hand, during Estonia's war of independence, at least until the summer of 1919, Estonians feared German goals of annexation. During the First World War the idea of uniting the whole of the so-called historic Baltic area (the Estonian, Livonian and Courland Governorates, which corresponded quite closely with the residential areas of Estonians and Latvians) to Germany emerged, in the form of a Duchy. At the same time the traditional dominance of Germans would be preserved. Even Germany's defeat in the world war did not immediately remove this fear, as the Estonians (and Latvians) perceived the German anti-Bolshevik free forces operating in the Baltic as continuing to advance Germany's ambitions for dominance in the area. ${ }^{11}$

The significance of other minorities was limited in both countries. About 4000 Jews lived in Estonian cities, and their role in the economy and in professional education was significantly greater than their proportion of the population. In this sense, the Jews resembled the Germans a little, but the essential difference was that the Jews owned very little land and they had been stripped of any political power under Imperial Russian rule. ${ }^{12}$ The Jews also did not have any "home state", which would have taken interest in the situation of Jews in Estonia. Therefore, Estonians only needed to take the Jews into account because the number of Jews in the country was not but negligible and because the Jews had moderate economic and educational potential. The Poles and Finns followed the Jews in number, but as groups of 1000-2000 people they were quite marginal. ${ }^{13}$

In Finland, all others besides the Swedes were such minimal minority groups, that in the early years of independence they were not taken into account in decision-making at all. Members of the Russian civil service that had settled mostly in southern Finnish cities during the period of Imperial Russian rule largely left the country at the time of Finnish independence, and

\footnotetext{
${ }^{11}$ Laurits 2008, pp. 29-40; Ruutsoo 1993, pp. 6-7.

${ }^{12}$ Alenius 2003, pp. 44-47; Ruutsoo 1993, p. 8.

${ }^{13}$ Alenius 2003, pp. 48-49; Ruutsoo 1993, pp. 8-9.
} 
the refugees that arrived in Finland during the Russian Civil War were a highly fragmented group. ${ }^{14}$ There were no Russian settlements on the eastern Finnish borders that would have been problematic from a perspective of potential separatism. The Sami and Roma, both of which had a few thousand people, were also socially unorganized. The number of Jews (about 1000 people) and other minorities was so small, that in practice they were virtually unnoticeable in Finland. ${ }^{15}$

Concerns about possible minority separatism were common everywhere in Eastern Europe in the 1920s, as all states had larger or smaller border areas in which a significant number of citizens, or even a majority, were part of a nationality whose original state was located just on the other side of the border. ${ }^{16}$ This is why both Finland and Estonia carried out various measures during the early years of their independence in order to weed out possible separatist ideas.

Germany faced exactly the same problem as Finland and Estonia. During 1918-1919 in general, the treatment of minorities in Germany was interpreted as having significance precisely from the perspective of how these groups related to Germany and how strongly groups would attempt or not attempt - to separate their residential areas from the context of the German state. The share of national minorities out of the total population was small (approx. $8 \%$ ), but as the Polish minority constituted a local majority in several regions in the eastern border areas, the holders of power in Berlin had to take the Polish issue very seriously. ${ }^{17}$

Finland and Estonia were also similar in that the main population of both countries had taken a side stage in exercising power for hundreds of years. With regard to exercising power, both the Finns and the Estonians had

\footnotetext{
${ }^{14}$ Natalia Baschmakoff \& Marja Leinonen, Russian Life in Finland 1917-1939: A Local and Oral History (Helsinki: Tomus 2001), pp. 35-57.

15 Toivo Nygård, Erilaisten historiaa. Marginaaliryhmät Suomessa 1800-luvulla ja 1900-luvun alussa (Jyväskylä: Atena 1998), pp. 108-114; Juha Pentikäinen, "Uskonnollis-kulttuuriset vähemmistöt", in: Pentikäinen \& Hiltunen 1997, pp. 185-188.

${ }^{16}$ Hobsbawm 1990, pp. 143-144; Pearson 1983, pp. 184-185.

17 Alenius 2011, pp. 204-205; Panikos Panayi, Ethnic Minorities in Nineteenth and Twentieth Century Germany: Jews, Gypsies, Poles, Turks and Others (Harlow: Pearson Education 2000), pp. 54-59.
} 
been minorities, even if their numbers were much greater than the population of other groups in total. In Finland, power had traditionally belonged to the Swedish-speaking population, and in Estonia to Germans. Towards the end of tsarist rule, Russian officials had also reinforced their position as a second, external group to hold power. In both countries the main nationality's participation in the use of power had become stronger during the early years of the 20th century, but the situation did not change fully until the countries became independent. ${ }^{18}$

In Germany, the Germans had naturally been the leading ethnic group even before 1918, but there also wide societal changes were nevertheless not only a general basis but also a necessary condition for the revision of minority policies. Improving the status of minorities became a serious issue of debate among the German political elite only after defeat in the war was a foregone conclusion. In order to safeguard German national interests in the post-war settlement it was no longer possible for the political elite to overlook the national needs and demands of minorities in the same way as occurred during the last decades of the Imperial period. ${ }^{19}$

Thanks to their very strong quantitative majority position, the Finns and the Estonians - as well as the titular nation in Germany - became such strong authorities that, had they wanted to, they could have fully dictated their will to others. Consequently, the previous power groups in Finland and Estonia became small minority groups who found it psychologically hard to accept such a sudden change in their position. From this perspective, too, Finland and Estonia can be compared with most of the small and mediumsized countries in Eastern Europe. In practice, similar transfers in power took place in all the new states, to the benefit of the states' original nationalities. ${ }^{20}$

\footnotetext{
${ }_{18}$ Allardt \& Starck 1981, pp. 153-176; Liebkind, Broo \& Finnäs 1997, pp. 68-72; Ruutsoo 1993, pp. 6-7.

${ }_{19}$ Sitzung des Kriegskabinetts 6.10.1918, in Erich Matthias \& Rudolf Morsey (Hrsg.), Die Regierung des Prinzen Max von Baden. Quellen zur Geschichte des Parlamentarismus und der politischen Parteien. Erste Reihe, Band 2 (Düsseldorf: Droste Verlag 1962), pp. 90-91.

${ }^{20}$ Hobsbawm 1990, pp. 133-134; Laurits 2008, pp. 29-30; Pearson 1983, p. 185.
} 


\section{Differences of opinion and the choosing of a tolerant minority policy}

With regard to minority issues, the most central thing to be decided after independence was how the Finns and the Estonians would use their position of power. There were two options: 1) rough use of power, which aimed to absorb the minorities into the majority population, thus gradually lessening the significance of the minority question over time, or 2) a policy supporting the culture and identity of the minorities, which would aim to encourage the minorities to feel loyalty towards the majority population and the state. Most of the countries in Europe in the interwar period chose to practise the first option of absorbing the populations.

However, Finland and Estonia chose differently and started to apply exceptionally positive policies towards the national minorities. There is no clear answer as to why they chose to do this, but some of the following factors could have been part of the reason: 1) The Finns and Estonians understood that they were small nations, and it would be unrealistic for them to try to enforce their will through strength, especially in the international context. Rather, they should attempt to create and maintain practises where strength was not the decisive factor, but where the perspectives of all parties - both large and small - were taken into account through negotiations. 2) Both countries lacked the traditions of open rebellion or other political violence. 3) The new national elite had personal experience of minority status, which helped them understand the situation of minorities also after the status of power changed; they also had experience on how they had been able to improve the position of their own group through peaceful methods in the end of the 19th century and the beginning of the 20th. 4) High level of education and high quality of living in relation to the period, which created the background for fact-based consideration of the minority issues. 5) The small share of the minorities in the population, which brought some level of certainty that the minorities would not be a serious threat to the existence of the whole state and the fundamental power of the main nationality. 6) During the Wars of Independence in 1918-1920, the Finnish and Estonian authorities wanted to ensure the minorities' 
support for the government, the position of which was seriously endangered.

Both countries naturally had a lot of discussion concerning minority policies in 1917-1920. Both Finland and Estonia had parties and interest groups that saw the rights granted to the minorities as unfounded privileges which harmed the interests of the state and the majority population. ${ }^{21}$ On the other hand, the minorities also had extremist groups who were critical towards the actions of the majority population and the government, despite their exceptionally positive overall approach in international comparisons. Both the Swedes and the Russians in both countries brought up separatist ideas, but the support for these thoughts remained quite insignificant in the end. ${ }^{22}$ It is probable that the positive minority policies helped smooth out the moods of the minorities.

In Finland, the views of political groups regarding minority issues structurally resembled the situation in almost all European countries. In Europe generally, liberal centrist and moderate leftists (Social Democratic) parties were more prepared to accept the granting of extensive rights to national minorities. ${ }^{23}$ From their perspective, general civil rights belonged to minorities, and additionally, due to their weaker position, minorities were entitled to some degree of protection or support measures to ensure that they had the possibility of maintaining their national-cultural characteristics. This is why for example, in Czechoslovakia, minorities were guaranteed education in their native language if their percentage of the local population exceeded twenty percent. ${ }^{24}$ In Finland, the two major parties, the Social Democrats and the moderately nationalist Agrarian League supported a policy that slightly favored minorities. ${ }^{25}$ Minority legislation enacted during

\footnotetext{
${ }^{21}$ Allardt \& Starck 1981, pp. 187, 192-195; Laurits 2008, p. 33; Liebkind, Broo \& Finnäs 1997, pp. 68-69.

${ }_{22}$ Allardt \& Starck 1981, pp. 186-188, 197; Lõuna 2003, pp. 84-86, 110.

${ }^{23}$ Hobsbawm 1990, pp. 145-150.

${ }^{24}$ Helmut Slapnicka, "Majorities and Minorities in an Inverted Position: Czechoslovakia, 1918-1939", in Sergij Vilfan, Gudmund Sandvik \& Lode Wils (Eds.), Ethnic Groups and Language Rights. Comparative Studies on Governments and Non-dominant Ethnic Groups in Europe, 1850-1940. Volume III (New York: New York University Press 1993), pp. 176-190.

${ }^{25}$ Allardt \& Starck 1981, pp. 192-197; Saukkonen 2013, pp. 97-102.
} 
the era of Finnish independence is largely due to the activity of these two parties.

Similarly, the nationalist conservative right was most skeptical about minorities in Finland as in most European countries, for example in Germany or Sweden. For them, their own nationality - usually nationality as determined by the state, such as the French in France or Spanish in Spain was primary, and society had to be constructed so as to ensure its interests. Minorities could not be given anything that would have essentially been in conflict with the interests of the majority of the population. If minorities were given support, for example education in their own language, the amount of support could not be greater than what the minority's share of the population directly necessitated. Anything else would have been providing the wrong kinds of privileges to minorities. If minorities were given the right to create self-governing institutions, the conservative right feared that they would form a "state within a state", which again would be absolutely contrary to the interests of the state and the majority of the population. In practice, nationalist movements such as the Finnish movement in Finland desired a reduction in the number of minorities and in their social role. For some, the desirable end point seemed to be the assimilation of minorities into the majority. ${ }^{26}$

Regarding the attitude of the Left, it should be borne in mind, however, that the issue was a two-edged sword. The example of Germany reveals this very clearly. According to the ideological axiom of the Left national minorities did not need any special attention in comparison to others who had a social disadvantage, especially those who were economically and socially "oppressed". Left-wing ideology in Germany and elsewhere basically excluded those kinds of arrangements based on nationality which could have been interpreted as privileges or were otherwise against general equality. In any case, the German Left criticized

\footnotetext{
${ }^{26}$ Alenius 2011, pp. 205-206; Allardt \& Starck 1981, pp. 192-196; Laurits 2008, pp. 144-146; Sergij Vilfan, "Introduction”, in: Vilfan, Sandvik \& Wils 1993, pp. $2-5$.
} 
the minority policies of the Imperial period and were in favor of some degree of reform. ${ }^{27}$

In Estonia, the situation was even more complicated, due to the exceptional role of Germans in the country's history. In Estonia is in Latvia, for centuries the ethnic border had been congruent with the other internal borders of society. In Finland, the situation of Swedes somewhat resembled this, but the demarcating line was much more benign and was easier to cross. In the Baltic region the Germans as a closed group had dominated all areas of power, politics, culture and economics. ${ }^{28}$ Therefore, in Estonia (and Latvia) the question of nationality was at the same time a social question concerning all aspects of life. The promotion of equality in any area inevitably meant intervening in the traditional dominant position of Germans. Further afield in Europe, the same situation could be found in Austria-Hungary. There, in the Slavic areas of Austria, the German minority had had a dominant role in all spheres of life, as the Hungarians had in the Slavic or Roman areas of the dual monarchy of Hungary. ${ }^{29}$

In Estonia the attitude of political parties towards minorities was, in light of the preceding background, exceptional by international standards. Most sympathetic towards considering minority rights was the conservative right, which at the time of independence was represented by the Rural League (Maaliit). The activities of the conservative right reveal that in its world view and social thought, of the Estonian parties it was closest to the Baltic German bourgeoisie. The conservatives were more willing to acknowledge that economically and culturally the Germans had had much to give to the Estonians, although in principle the conservatives also supported ethnic Estonian nationalism. However, the nationalism of Estonian conservatives was based on equality between nationalities and on taking national perspectives into account in all societal decision-making.

\footnotetext{
27 18. Sitzung 31.3.1919, Mündlicher Bericht des 8. Ausschusses über den Entwurf einer Verfassung des Deutschen Reiches. Bundesarchiv, R101, 2901,93.

${ }^{28}$ Liebkind, Broo \& Finnäs 1997, pp. 68-72; Ruutsoo 1993, pp. 6-7.

${ }^{29}$ Sergij Vilfan, “An Ethnic Mosaic: Austria before 1918”, in Vilfan, Sandvik \& Wils 1993, pp. 111-130.
} 
This included guaranteeing minorities the opportunity of preserving their own national-cultural characteristics. ${ }^{30}$

Respectively, the political left and center in Estonia, including the liberals, were more reluctant to grant rights to minorities. The vast majority of parties wanted to immediately implement large-scale land reforms, in which the landed property of Germans would be confiscated and in the same context the transfer of social power from Germans to Estonians would be ensured. This transfer of power was not easy to reconcile with guaranteeing the rights of minorities. Estonian political parties were only ready to expand the rights of minorities after land reform and thereby a kind of social and national revolution had taken place. After this, deeper structural factors could have influence, those that were previously presented in the form of six main points. The end result was that in Estonia in the early 1920s, there began to be implemented a policy that was, by international standards, sympathetic towards minorities, although the critical voices then belonged to the left. The left feared that Germans would attempt to maintain "unjustified privileges" and that they would even seek to restore their leading economic position in Estonia. It took until the mid-1920s before such fears were left on the margins of political debate. ${ }^{31}$

The differences between Estonian political parties were concretely evident in the first months of independence. From November 1918 to May 1919 the conservative right side had a leading role in the Estonian provisional government, and the government clearly chose a policy that guaranteed the rights of minorities. Estonians "did not have to take the poor example of their former rulers" (Germans and Russians), but could also recognize the rights of national minorities. ${ }^{32}$ The Estonian Declaration of Independence itself was directed to "all the nations of Estonia", instead of referring to "the people" or "the Estonian nation" in the singular. ${ }^{33}$ Therefore, the government wanted to emphasize that alongside ethnic

\footnotetext{
${ }^{30}$ Alenius 2003, pp. 376-378.

${ }^{31}$ Alenius 2003, pp. 377-379.

${ }^{32}$ Maanõukogu protokoll (Minutes of the Estonian Provincial Assembly) 20.11.1918 (Tallinn 1935).

${ }^{33}$ Estonian Declaration of Independence 24.2.1918, in Riigi Teataja 27.11.1918.
} 
Estonians, minority nationalities were recognized and were equal groups to the majority population. Immediately after independence, the Finnish government also chose a policy whereby representation for the Swedish speaking population was secured at the highest level of power.

As far as participation in the highest power was concerned, Germany deviated from Finland and Estonia. Both the German central government and the state governments held power firmly in their own hands. Representatives of national minorities were not invited to the governments, and minorities were not recruited to a significant extent by the regional government service. Prussia and Saxony were those of the German states who had the largest number of national minorities, both proportionally and quantitatively. During 1918-1919, both Länder carried out a number of legislative reforms that improved the cultural freedom of minorities and provided the opportunity for education in their own language (Polish and Sorbian). ${ }^{34}$ Probably the long established status of Germany as a Great Power explains the fact that, despite such cultural concessions, the German elite did not want to engage minority groups in actual political decision-making.

On the other hand, the rulers of Estonia, Finland and Germany regarded certain uses of force as necessary, so that minorities would not endanger national security. In Finland, soldiers of the Russian army, of which about 100,000 had settled in the country, were regarded as a risk. The majority of them voluntarily returned to Russia in the autumn of 1917 and early 1918, when in practice the detachments of the Russian army scattered. However, in the summer of 1918 the Finnish government decided to deport the last of about 20,000 men who would have wished to remain living as civilians in Finland. In addition to security aspects this decision was possibly influenced by a general distrust of Russians in Finland. The Russians were considered ethnically and culturally foreign and as representatives of a foreign Tsarist tyranny. ${ }^{35}$ Even if the Russians were not persecuted, there was

\footnotetext{
34 Preussische Gesetzsammlung, Jahrgang 1918, Nr. 39; Reichs-Gesetzblatt, Jahrgang 1919, nr. 152; Amtliches Schulblatt für den Regierungs-Bezirk Allenstein, Nr. 11 (1919).

${ }^{35}$ Baschmakoff \& Leinonen 2001, pp. 37-42; Nygård 1998, pp. 117-129.
} 
no desire to provide them with specific minority rights, and the growth of their numbers in Finland was not considered desirable.

Among the Russian population living in Petseri County in Estonia in 1919-1920 there was widespread mistrust towards the authorities in Estonia, and a number of individuals were involved in outright political agitation to reconnect the region with Russia. To de-escalate the situation, the Estonian government appointed a governor with exceptional powers in Petseri County, whose main task was to suppress the separatism emerging in the region. The means whereby this was accomplished was mainly by fine, dismissal from office and expulsion from the province. From the autumn of 1920 to the autumn of 1921 the governor appeared to be effective, as after this the provincial administration returned to its normal practices. ${ }^{36}$

In Germany, in the Prussian area in Posen the Poles began to revolt against the German government and soon managed to get the core parts of the province in their control in February 1919. In addition to pure military countermeasures, Prussia temporarily froze all the schemes relating to reforms in the status of minorities. Prussia re-evaluated the extension of minority rights in April when the situation had calmed down. To support the Polish language population's loyalty towards Germany, the Prussian government now required local authorities to actively implement the principle program that was sympathetic towards the Polish minority. On the other hand, the Prussian government feared growing Polish attempts to influence the opinions of two local ethnic groups who were uncertain of their identity, the Masurians and the Kashubians. In this case, Prussia opted for a policy, the content being that it was not necessary to increase the legal rights of these minorities. Instead, both the view of integration and the opposition to Polish hegemony supported the policy of assimilation. ${ }^{37}$

The positive approach of Finland and Estonia to the minorities was visible both in their legislation and practical matters. The provisional

\footnotetext{
${ }^{36}$ ERA F. 14, 1, 279 (1920), p. 71; ERA F. 14, 1, 578 (1921), p. 16; Riigi Teataja 141/142 (1920), pp. $1121-1122$.

37 Abschrift, Der Minister des Innern 2.7.1919, Geheimes Staatsarchiv Preussischer Kulturbesitz, I. HA, Rep. 84a, Nr. 1549,73; Amtliches Schulblatt für den Regierungs-Bezirk Allenstein, Nr. 11 (1919).
} 
Estonian government from November 1918 to April 1919 had three minority ministers representing the Swedes, Germans and Russians. From the summer of 1919 onwards, the government no longer had separate ministers for minority issues, but they were replaced with permanent secretariats for nationality matters established within the Ministry of the Interior. ${ }^{38}$ In Finland, the RKP (the Swedish People's Party of Finland) was included in the first four governments during independence until August 1919 and, after that, in two other governments in the beginning of the 1920s. ${ }^{39}$ In this regard, the closest comparison points to Finland and Estonia were Lithuania and Latvia, which also appointed ministers for the minorities to the governments during the early years of their independence. ${ }^{40}$

Legally, the position of minorities was secured in the Finnish constitution in 1919 and in the Estonian constitution in 1920. Both Acts secured the minorities the right to maintain their own culture through education in their own language, for example. In addition to this, they were secured the right to use their own language in municipal administration in those areas where the minority had a local majority. Furthermore, Finland gave the Swedes the right to seek service from the central bodies of the state in their own language, and Estonia also gave this right to the Swedes, Germans and Russians. ${ }^{41}$ The constitution defined relatively extensive basic rights to the minorities, and more acts clarifying these rights were legislated during the early years of the 1920s.

By international standards, the Estonian conservative right and interest groups for national minorities continued a rare cooperation in the early years of the 1920s. Although the 1920 Constitution already expressly

\footnotetext{
38 Asutava Kogu protokollid (Minutes of the Estonian Constituent Assembly) 14 (21.5.1919), 19 (28.5.1919), 23 (3.6.1919).

${ }^{39}$ List of Finnish Governments. URL: http://valtioneuvosto.fi/tietoa/historiaa/hallitukset-jaministerit/raportti/-/r/v2>, accessed 26.6.2016.

${ }^{40}$ Latvijas Republikas valdības. URL: http://www.mk.gov.lv/lv/content/ministru-kabinetavesture>, accessed 26.6.2016; Lietuvos ministru kabinetai. URL: https://ministraspirmininkas.lrv.lt/lt/apie-ministra-pirmininka/ankstesni-ministraipirmininkai/laikotarpiu-1918-1940, accessed 26.6.2016.

41 Constitution of Finland 1919. URL: http://www.finlex.fi/fi/laki/alkup/1999/19990731, accessed 26.6.2016; Constitution of Estonia 1920, in Riigi Teataja 113/114 (1920).
} 
guaranteed equal status for minorities with the majority of the population and the main minority groups had their own Secretariat for citizenship in the Interior Ministry, representatives of both groups held as their ideal a more in-depth consideration for national-cultural aspects. ${ }^{42}$ It can be mentioned here that in the beginning of 1925, Estonia adopted an internationally unique Cultural autonomy act of minorities. This Act gave all minority nationalities with at least 3,000 people the right to establish a national, self-governing organisation on the basis of personal autonomy.43

In Finland, the minority rights of Swedes were specified through two actions which were also unique in Europe during the interwar period. Firstly, Swedish and Finnish were defined as Finnish national languages which were fully equal all over the country. This definition was included in both the constitution and the complementary Language Act of 1922. What made this exceptional was the fact that the share of the Swedish-speaking population was only 11 percent of the whole population, and this equality was not regionally restricted. Elsewhere in Europe, minority languages were only granted an equal position in the areas inhabited by the minorities, it at all. The act also obligated all people employed by the Finnish state and municipalities to learn both languages so that they could serve all customers in all situations. ${ }^{44}$

Secondly, Finland granted exceptionally extensive autonomy to the Åland Islands. The Act on Åland's autonomy was adopted in 1920 and it was complemented two years later. In practice, Åland's own administrative bodies decide on all matters of the province, and other Finnish laws are only applied in part. The municipalities of Åland are Swedish-speaking and they are not obligated to serve their customers in Finnish. Åland is also a demilitarised area, and its residents are not conscripted, unlike all other

\footnotetext{
42 Alenius 2003, pp. 65-73, 107-109.

${ }^{43}$ Riigikogu protokollid (Minutes of the Estonian Parliament) 5.2.1925; Vähemusrahvuste kultuuriomavalitsuse seadus, in Riigi Teataja 31/32 (1925); Cornelius Hasselblatt, Minderheitenpolitik in Estland. Rechtsentwicklung und Rechtswirklichkeit 1918-1995 (Hamburg: Bibliotheca Baltica 1996), pp. 49-50; Laurits 2008, pp. 69-75; Ruutsoo 1993, pp. 12-13.

44 Kielilaki (Language Act, 1922). URL: http://www.finlex.fi/fi/laki/alkup/1922/19220148, accessed 26.6.2016.
} 
residents in Finland. The reason for Åland's near-independence was its residents' strong desire to become part of Sweden when Finland became independent. Finland and Sweden negotiated on the matter through the League of Nations, and as compensation for Finland keeping the islands, the state decided to ensure very extensive regional minority rights to Åland. ${ }^{45}$

In Finland, the attitude of dominant parties towards the Swedish speaking minority could be explained by attitudes similar to those of the Estonian conservative right towards Baltic Germans. Although on one hand the Swedes were envied because of their elite economic, political and cultural status, at the same time the Finnish educated classes recognized that in many ways Swedishness had been a positive factor in Finland's history. Many held the view that Finland had been connected to Western European civilization through Swedish domination, as Estonia had been through German domination. The alternative in this estimation would have been a connection with Russia and an "inferior" Eastern cultural sphere. ${ }^{46}$ In the late 1800s and early 1900s, when social Darwinism, racial thought and a very loaded cultural classification system prevailed, it was perceived that the issue in question was a decisive choice in terms of the whole past, present and future well-being of the nation. ${ }^{47}$ In Germany, the thinking model was the same, but its impact in practice was the opposite. Since Germany belonged to this "racially" and culturally highest reference group, it was questionable whether minorities could be truly equal in the eyes of the German elite.48

\section{Conclusions}

At the level of political rhetoric, the ideals of social and national equality were widely discussed throughout Europe in the aftermath of the First World War. However, in practice state nationalism formed as the dominant political course, in which the interests of the principal nationalities

\footnotetext{
45 Självstyrelselag för Åland (The Act on Åland's autonomy, 1920/1991). URL: http://www.finlex.fi/sv/laki/ajantasa/1991/19911144, accessed 26.6.2016.

46 Toomas Karjahärm, Unistus Euroopast (Tallinn: Argo 2003), pp. 27-36; Liebkind, Broo \& Finnäs 1997, pp. 50-51, 68-72.

${ }^{47}$ Hobsbawm 1990, pp. 107-109.

${ }^{48}$ For details, see Alenius 2011, 205-208.
} 
were the priority. Although the majority of rulers may have originally had sincere thoughts of applying the principles of national equality in their own country, in most cases a fear of social fragmentation and separatism led to the oppression of minorities or at the least, ignoring their rights. The League of Nations declared that it would advocate for the rights of minorities, but in the real world, even it did not do so. Finland and Estonia were perhaps the most obvious examples that belonged to that small group of states where local conditions made it possible to consider minority rights to a greater extent in practice.

When Finland and Estonia became independent at the end of the First World War, both countries had to create a completely new constitution. Attitude to minorities was one of the most important societal issues that the Constitution had to take a stand. The creation of the constitution lasted about two years, during which the minority issues were thoroughly considered. The new constitution came into force in Finland in 1919 and in Estonia in 1920.

The outcome of the process in both countries can be called exceptional to a certain extent. Due to the previously presented reasons Estonia and Finland adopted a very positive approach towards national minorities. Broad linguistic and cultural rights were given to minorities if the situation was compared with the rest of Europe.

Other countries with the closest similar policies were Latvia and Lithuania, where the overall social situation was largely the same as in Finland and Estonia, which means that the reasons can also be assumed to be similar. In all European countries, including not only the new states in Eastern Europe but also the old, established countries in Southern and Western Europe, minorities were granted more restricted rights. In addition, it should be noted that in many countries these laws were only theoretical and applied in practice in small amounts. Estonia and Finland were also exceptional compared to other countries in this regard, as the legislated minority acts were also applied almost in full.

Comparison with Germany shows that similar circumstances also forced a Great Power to act in the same direction when it comes to establishing relations with national minorities living in the country. When 
German society became democratic, the old authoritarian and nationalistic models were no longer sufficient to overcome the challenges. Groups that advocated universal social equality wanted to end the oppression of minorities. Groups that considered national values important and were socially liberal were prepared to give support to minorities and to pay specific attention to minorities in legislation. The clearest difference between Germany on one side and the Finland and Estonia on the other was that in a Great Power there was a a stronger need to keep the political power solely in the hands of the titular nation and respectively, a bigger threshold for distributing power to minorities as well at any level of administration.

This article has presented preliminary interpretations of what, in the case of Finland and Estonia, could explain the development of events. A systematic comparison of different countries may provide more reliable answers as to the validity of these interpretations, and whether there are theoretic models that can be identified in Europe as to what kind of historic and contemporary social issues correlate with the minority policies practiced.

\section{References:}

\section{A. Archives}

Bundesarchiv, R101.

Eesti Riigiarhiiv [Estonian National Archives] (cited as ERA), F. 4893.

Eesti Riigiarhiiv, F. 14.

Geheimes Staatsarchiv Preussischer Kulturbesitz, I. HA, Rep. 84a.

\section{B. Printed and electronic documents}

Amtliches Schulblatt für den Regierungs-Bezirk Allenstein, Nr. 11 (1919). Asutava Kogu protokollid 1919. Tallinn 1920.

Constitution

of

Finland

1919.

URL:

http://www.finlex.fi/fi/laki/alkup/1999/19990731, accessed at 26.6.2016. 
Kielilaki

(Language

Act,

1922).

URL:

http://www.finlex.fi/fi/laki/alkup/1922/19220148, accessed at 26.6.2016.

Latvijas

Republikas

valdības.

URL:

http://www.mk.gov.lv/lv/content/ministru-kabineta-vesture>, accessed at 26.6.2016.

Lietuvos ministru

kabinetai.

URL:

https://ministraspirmininkas.lrv.lt/lt/apie-ministrapirmininka/ankstesni-ministrai-pirmininkai/laikotarpiu-1918-1940, accessed at 26.6.2016.

List

of

Finnish

Governments.

URL:

http://valtioneuvosto.fi/tietoa/historiaa/hallitukset-ja-

ministerit/raportti/-/r/v2>, accessed at 26.6.2016.

Maanõukogu protokollid 1918. Tallinn 1935.

Matthias, Erich \& Morsey, Rudolf (Hrsg.). Die Regierung des Prinzen Max von Baden. Quellen zur Geschichte des Parlamentarismus und der politischen Parteien. Erste Reihe, Band 2. Düsseldorf: Droste Verlag 1962.

Preussische Gesetzsammlung, Jahrgang 1918, Nr. 39.

Reichs-Gesetzblatt, Jahrgang 1919, nr. 152.

Riigi Teataja 1918-1920.

Riigikogu protokollid 1925. Tallinn 1926.

Självstyrelselag för Åland (The Act on Åland's autonomy, 1920/1991). URL: http://www.finlex.fi/sv/laki/ajantasa/1991/19911144, accessed at 26.6.2016.

\section{Research literature and articles}

Alenius, Kari. Ajan ihanteiden ja historian rasitteiden ristipaineissa. Viron etniset suhteet vuosina 1918-1925. Rovaniemi: PSHY 2003.

Alenius, Kari. Compromise solutions through careful consideration. The development of the legal status of national minorities in Germany, 19181919. Rovaniemi: PSHY 2011.

Allardt, Erik \& Starck, Christian. Vähemmistö, kieli ja yhteiskunta. Helsinki: WSOY 1981. 
Ant, Jüri. Eesti 1920. Iseseisvuse esimene rahuaasta. Tallinn: Olion 1990.

Baschmakoff, Natalia \& Leinonen, Marja. Russian Life in Finland 1917-1939: A Local and Oral History. Helsinki: Tomus 2001.

Beller, Manfred. "Perception, image, imagology". In Beller, Manfred \& Leerssen, Joep (Eds.). Imagology. The cultural construction and literaty representation of national characters. A critical survey. Amsterdam: Rodopi 2007.

Fält, Olavi K. "Introduction”. In Alenius, Kari, Fält Olavi K. \& Jalagin, Seija (Eds.). Looking at the Other: Historical study of images in theory and practice. Oulu: Oulun yliopisto 2002. Göthel, Thomas. Demokratie und Volkstum. Die Politik gegenüber den nationalen Minderheiten in der Weimarer Republik. Köln: SH-Verlag 2002.

Hasselblatt, Cornelius. Minderheitenpolitik in Estland. Rechtsentwicklung und Rechtswirklichkeit 1918-1995. Hamburg: Bibliotheca Baltica 1996.

Hobsbawm, Eric J. Nations and Nationalism since 1780. Cambridge: Cambridge University Press, 1990.

Karjahärm, Toomas. Unistus Euroopast. Tallinn: Argo 2003.

Laurits, Kaido. Saksa kultuuromavalitsus Eesti Vabariigis 1925-1940. Tallinn: Rahvusarhiiv 2008.

Liebkind, Karmela, Broo, Roger \& Finnäs, Fjalar. "Suomen ruotsinkielinen vähemmistö". In Pentikäinen, Juha \& Hiltunen, Marja. Suomen kulttuurivähemmistöt. Helsinki: Suomen Unesco-toimikunta 1997.

Lõuna, Kalle. Petserimaa. Petserimaa integreerimine Eesti Vabariiki 1920-1940. Tallinn: Eesti entsüklopeediakirjastus 2003.

Matsulevitš, Anni (Ed.). Vähemusrahouste kultuurielu Eesti Vabariigis 19181940. Tallinn: Olion 1993.

Nygård, Toivo. Erilaisten historiaa. Marginaaliryhmät Suomessa 1800-luvulla ja 1900-luvun alussa. Jyväskylä: Atena 1998.

Panayi, Panikos. Ethnic Minorities in Nineteenth and Twentieth Century Germany: Jews, Gypsies, Poles, Turks and Others. Harlow: Pearson Education 2000.

Pearson, Raymond. National minorities in Eastern Europe 1848-1945. London: Macmillan 1983. 
Pentikäinen, Juha \& Hiltunen, Marja. Suomen kulttuurivähemmistöt. Helsinki: Suomen Unesco-toimikunta 1997.

Pentikäinen, Juha. "Uskonnollis-kulttuuriset vähemmistöt". In Pentikäinen, Juha \& Hiltunen, Marja. Suomen kulttuurivähemmistöt. Helsinki: Suomen Unesco-toimikunta 1997.

Ratz, David. "The Study of Historical Images". In Faravid. Journal for Historical and Archaeological Studies 31/2007.

Ruutsoo, Rein. "Rahvusvähemused Eesti Vabariigis". In Matsulevitš, Anni (Ed.). Vähemusrahouste kultuurielu Eesti Vabariigis 1918-1940. Tallinn: Olion 1993.

Saukkonen, Pasi. Erilaisuuksien Suomi. Helsinki: Gaudeamus 2013.

Slapnicka, Helmut. "Majorities and Minorities in an Inverted Position: Czechoslovakia, 1918-1939". In Vilfan, Sergij, Sandvik, Gudmund \& Wils, Lode (Eds.). Ethnic Groups and Language Rights. Comparative Studies on Governments and Non-dominant Ethnic Groups in Europe, 1850-1940. Volume III. New York: New York University Press 1993.

Vilfan, Sergij. “An Ethnic Mosaic: Austria before 1918”. In Vilfan, Sergij, Sandvik, Gudmund \& Wils, Lode (Eds.). Ethnic Groups and Language Rights. Comparative Studies on Governments and Non-dominant Ethnic Groups in Europe, 1850-1940. Volume III. New York: New York University Press 1993.

Vilfan, Sergij. "Introduction". In Vilfan, Sergij, Sandvik, Gudmund \& Wils, Lode (Eds.). Ethnic Groups and Language Rights. Comparative Studies on Governments and Non-dominant Ethnic Groups in Europe, 1850-1940. Volume III. New York: New York University Press 1993. 